\title{
AGR-1 Source Inspection Report For First Inspection
}

Gary D. Roberts

Charles M. Barnes

October 2005

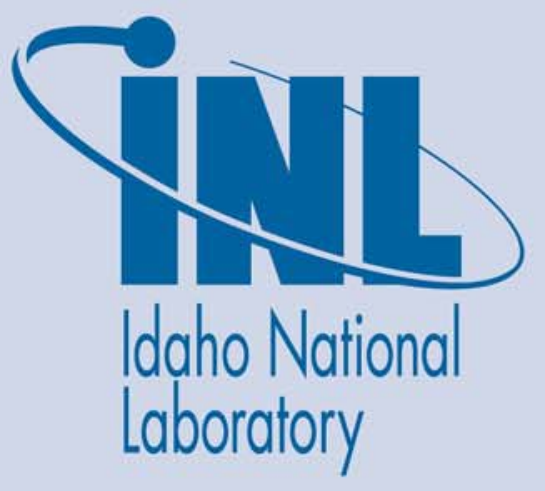

The INL is a U.S. Department of Energy National Laboratory operated by Battelle Energy Alliance 
INL/EXT-05-00819

\title{
AGR-1 Source Inspection Report for First Inspection
}

\author{
Gary D. Roberts and Charles Barnes
}

October 2005

\author{
Idaho National Laboratory \\ Idaho Falls, Idaho 83415
}

\author{
Prepared for the \\ U.S. Department of Energy \\ Office of Nuclear Energy Science and Technology \\ NE-20, Advanced Nuclear Research \\ Under DOE Idaho Operations Office \\ Contact DE-AC07-05ID14517
}




\title{
AGR-1 Source Inspection Report for First Inspection
}

\author{
INL/EXT-05-00819, Rev. 0
}

October 2005

Approved by

Gary D. Roberts

Charles M. Barnes

John R. Cox
Date

Date

Date 


\section{AGR-1 Source Inspection Report for First Inspection}

\section{OBJECTIVE}

Battelle Energy Alliance (BEA) of the Idaho National Laboratory completed a source inspection at Oak Ridge National Laboratory on September 7 and 8th, 2005. The objective of this inspection was to ensure that all required data collection forms, data collection processes and methods of data acceptance are in place prior to starting the first Advance Gas Reactor (AGR) particle coating production run. Material traceability and calibration requirements defined for Measuring and Test Equipment (M\&TE) were also reviewed during this inspection.

\section{SUMMARY OF RESULTS}

The schedule for the first source inspection for AGR-1 fuel was established to coincide with the completion of coating process qualification work and ORNL readiness to produce TRISO fuel in accordance with the AGR-1 fuel specification EDF-4380. In addition to the fuel specification, required process parameters were identified in a D.A. Petti letter Subject: Distribution, Baseline and Variant Processing Conditions for Advanced Gas Reactor, CCN 201231, dated June 1, 2005.

The inspection revealed several deficiencies. ORNL data collection forms, data collection processes and methods of data acceptance were in place except for three items listed in inspection specifics, Section 4.4. Material traceability was well documented with no deficiencies identified. During the inspection process, it was identified that several of the coating process parameters ORNL intended to use for production of the AGR-1 baseline TRISO did not match the process parameters required by the fuel specification and direction provided in the D. A. Petti letter listed above. These parameters include coating gas temperatures for Buffer, IPyC, and $\mathrm{OPyC}$, and an increase in the temperature tolerances $\left( \pm 15^{\circ} \mathrm{C}\right.$ vs. $\left.\pm 10^{\circ} \mathrm{C}\right)$ for IPyC and OPyC coating gas temperatures. ORNL had notified the program of these process changes in a June $30^{\text {th }}$ letter documenting the completion of coating baseline process development however, the coating process parameter changes were not identified to or by all program members. This resulted in no Technical Coordination Team (TCT) discussion of the changes, the fuel specification was not changed to reflect coating process qualification parameters and the R\&D Technical Director for AGR Fuel Development and Qualification Program did not approve the changes.

Although outside the scope, during the inspection it was identified that the SiC layer on the TRISO fuel had "gold spots" indications in the excess of the fuel specification requirements. This is included in the inspection report because it is consider an inspection prerequisite that was not completed. Therefore, this prerequisite must be resolved prior to inspection closeout.

Subsequent to the source inspection and associated deficiency identifications, the TCT has had several telephone conferences discussing the process parameter changes. Upon program acceptance by the R\&D Technical Director, product and/or process parameter changes will require a revision to the INL fuel specification and an ORNL fuel coating process qualification must be completed to demonstrate compliance with the specification. 


\section{SCOPE AND LOGISTIC}

The team consisted of a Quality Assurance representative (QA) and a technical expert from the INL. The QA representative was Gary D. Roberts and the technical expert was Charles M. Barnes.

The INL source inspection plan (PLN-1930), was developed and approved on April 13, 2005. This plan was revised to reorganize inspection points, and approved on August 29, 2005. The date of the first source inspection was scheduled to coincide with the completion of ORNL coating process qualification work and readiness to produce TRISO fuel for AGR-1. A source inspection checklist was developed based on the fuel specification and letter CCN 201231, which identified all items that would be verified. This checklist also agreed with the Technical Coordination Team Meeting Summary dated May 13, 2005, where IPyC characteristics and requirements were discussed in detail. The checklist was forwarded to ORNL on July 26, 2005, to identify the scope of the inspection. Based on this checklist, ORNL forwarded the applicable Product Inspection Plans (PIP) and Data Acquisition Methods (DAM) documentation to the INL for initial review prior to the inspection. These documents were reviewed by INL QA. The checklist was updated to reflect the review and the updated inspection checklist was sent to ORNL on August 31, 2005, noting potential discrepancies in the ORNL data collection forms.

During the inspection, the INL inspection team met with ORNL personnel, toured ORNL AGR fuel fabrication and characterization facilities, reviewed process documentation, M\&TE records and material traceability.

Key ORNL personnel contacted/interviewed during the evaluation included:

Gary Bell

Mark Vance

John Hunn

Richard Lowden

Gerald Jellison

\section{INSPECTION SPECIFICS}

4.1 ORNL personnel were very cooperative, professional and helpful during the inspection. All records reviewed were neat and easily retrievable. M\&TE records were reviewed for each piece of equipment used during the fuel coating and characterization process. All M\&TE except the inclinometer noted in Section 4.4.1 were properly calibrated and ready for use. Material traceability was well documented with no deficiencies identified. DAMs and PIPs reviewed during the inspection process are listed in Attachment B.

4.2 ORNL letter AGR-1036, 30Jun05, from G.L. Bell to M.A. Feltus, Subject: DEAC05-00OR22725, Notification of Completion of Deliverable, “AGR Task 


\subsubsection{1, Complete Coating Baseline Process Development for AGR-1"} identified changes is process temperatures and their tolerances. The coating process parameter changes were not identified to or by all program members. This resulted in no TCT discussion of the changes, the fuel specification was not changed to reflect required coating process qualification parameters and the R\&D Technical Director did not approve the changes. The AGR-1 Fuel Product Specification and Characterization Guidance, EDF-4380, Revision 3, provides product and process specifications for the AGR-1 fuel coating process. The following ORNL process parameters were found to depart from the fuel specification:

4.2.1 ORNL was planning to use an IPyC temperature of $1265^{\circ} \mathrm{C}$ to achieve a layer density closer to the fuel specification. Fuel specification temperature was $1250 \pm 10{ }^{\circ} \mathrm{C}$.

4.2.2 OPyC coating gas temperature has yet to be finalized but it is expected to be 1265 to $1285{ }^{\circ} \mathrm{C}$. Specification temperature was $1250 \pm 10^{\circ} \mathrm{C}$.

4.2.3 Tolerances for IPyC and OPyC coating gas temperatures were $\pm 10^{\circ} \mathrm{C}$. Based on discussion with Richard Lowden, the tolerances need to be $\pm 15{ }^{\circ} \mathrm{C}$.

4.2.4 Variant 1 IPyC temperature was $1275 \pm 5^{\circ} \mathrm{C}$. If a IPyC baseline fuel temperature of $1265 \pm 15^{\circ} \mathrm{C}$ is used, an overlap with Variant 1 IPyC temperature would exist.

4.2.5 The buffer coating temperature was planned to be $1350{ }^{\circ} \mathrm{C}$ to achieve a density closer to the specification mean. Fuel specification temperature was $\sim 1275{ }^{\circ} \mathrm{C}$.

4.3 The following fuel characterization characteristic was found to depart from the fuel product specification:

4.3.1 Examination of particles for gold spots revealed 34 particles out of 12,000 with features that could be considered "gold spots." The fuel product specification for SiC gold spots is $\leq 1.0 \times 10^{-3}$.

4.4 The following items were found deficient in ORNL documentation for AGR-1 fuel coating characterization:

4.4.1 The tabling procedure, AGR-Table-SOP-01, requires a calibrated inclinometer for setting the slope of the table during initial setup or prior to use. A calibrated inclinometer with a certification of calibration was not available to support tabling operations. After the inspection, ORNL supplied objective evidence that the tabling procedure has been revised, not requiring instrument calibration. No further action is required.

4.4.2 PIP-02, Inspection Report Form IFR-02A, and PIP-04, Inspection Report Form IFR-04, data collection sheets identify the Buffer Envelope Density as $0.95 \pm 0.15$. The Buffer Envelope Density 
specification has been changed to $1.05 \pm 0.20$ in revision 3 of the fuel specification. After the inspection, ORNL supplied objective evidence that the forms have been corrected. No further action is required.

4.4.3 AGR-Coat-SOP-01, Standard Operating Procedure for Fluidized Bed Chemical Vapor Deposition System, did not list on the data collection sheets the acceptance values in the AGR-1 fuel specification for the coating process. There was no identified location for a QA review of the data. The data sheets were revised during the inspection to include all coating process parameters and a QA review. No further action is required.

\section{OBSERVATIONS:}

5.1 ORNL requested that a roller micrometer ("roller-mike" per AGR-Roller-SOP01 Rev. 0) replace the sieves in product classification. Richard Lowden provided data to show advantages of this new process over the process using sieves. If approved for use, the fuel specification needs to be changed to reflect the "roller-mike" process.

5.2 ORNL is taking more samples than required in the sampling plan; in no case was ORNL taking fewer samples than required in the sampling plan. The ORNL sampling process was reviewed with Jeff Einerson at the INL, and the ORNL process was determined not to be a problem.

\section{ACTIONS REQUIRED FOR CLOSEOUT OF THE FIRST AGR FUEL INSPECTION}

6.1 Subsequent to the source inspection, Gary Bell issued a letter to David Petti, ORNL Action on Items from QA Source Inspection No. 1, AGR-1040, dated September 14, 2005. This letter addressed the completion of ORNL actions. Based on guidance from the R \& D Technical Director, the following additional ORNL and INL actions are considered necessary for closure of source inspection 1:

6.1.1 ORNL needs to correct process conditions to alleviate the $\mathrm{SiC}$ laminar defects.

6.1.2 INL will modify the fuel specification to allow use of the "roller-mike". ORNL will provide INL with any additional information required to resolve questions using the "roller-mike".

6.1.3 INL will update the AGR-1 Fuel Product Specification and Characterization Guidance, EDF-4380 to reflect changes in the process and/or product parameters.

6.1.4 ORNL will update their PIP and DAM documentation to reflect the updated parameter requirements when EDF-4380, Rev. 4 is issued.

6.1.5 INL QA will review updated ORNL PIPs and DAMs associated with the revised fuel inspection to ensure that documentation is ready for fuel coating and characterization. This review will be performed prior to initiating fuel coating of AGR-1 baseline TRISO fuel. This will be a 
"table top" review conducted at INL and will take place when the following conditions are completed:

- the INL fuel specification is revised and distributed

- ORNL PIPs and DAMS have been updated to reflect changes in the revised fuel specification.

- all required ORNL fuel coating qualification runs have been completed

\section{ATTACHMENTS}

A. Source Inspection Checklist for the First AGR Fuel Inspection.

B. List of Documents Reviewed. 


\section{Source Inspection Report for $1^{\text {st }}$ Inspection Attachment B \\ INL/EXT-05-00819 List of Documents Reviewed \\ Rev. 0}

1. Product Inspection Plan, Interrupted Coating Batches, AGR-CHAR-PIP-02 Rev. 2, Date 6/15/05

2. Product Inspection Plan, Coated Particle Batches, AGR-CHAR-PIP-03 Rev. 1, Date 7/14/05

3. Product Inspection Plan, Coated Particle Composites, AGR-CHAR-PIP-04 Rev. 1, Date 6/30/05

4. Data Acquisition Method, Measurement of SiC Density Using a Density Gradient Column, ARGCHAR-DAM-02 Rev. 0, Date 4/15/05.

5. Data Acquisition Method, Measurement of PyC Density Using a Density Gradient Column, ARG-CHAR-DAM-03 Rev. 0, Date 4/15/05.

6. Data Acquisition Method, Preparation of Liquid Density Gradient Column for Measurement of SiC Density, ARG-CHAR-DAM-04 Rev. 0, Date 4/15/05.

7. Data Acquisition Method, Preparation of Liquid Density Gradient Column for Measurement of PyC Density, ARG-CHAR-DAM-05 Rev. 0, Date 4/15/05.

8. Data Acquisition Method, Imaging of Particle Diameter and Aspect Ratio Using Optical Microscope System, ARG-CHAR-DAM-07 Rev. 0, Date 4/15/05.

9. Data Acquisition Method, Imaging of Particle Cross Sections Using Optical Microscope System, ARG-CHAR-DAM-08 Rev. 0, Date 4/15/05.

10. Data Acquisition Method, Imaging of Particle Diameter and Aspect Ratio Using Image Analysis, ARG-CHAR-DAM-10 Rev. 0, Date 4/15/05.

11. Data Acquisition Method, Measurement of Coating Layer Thickness Using Image Analysis, ARG-CHAR-DAM-11 Rev. 0, Date 4/05/05.

12. Data Acquisition Method, Preparation of Polished Coated Particle Cross-sections for Measurement of Anis0tropy, ARG-CHAR-DAM-12 Rev. 0, Date 4/15/05.

13. Data Acquisition Method, Preparation of Particle Polished Cross-sections for SEM, ARG-CHARDAM-13 Rev. 1, Date 6/29/05.

14. Data Acquisition Method, Preparation of Particle Polished Cross-sections for Optical Imaging, ARG-CHAR-DAM-14 Rev. 1, Date 6/29/05.

15. Data Acquisition Method, Measurement of Buffer Envelope Density using a Mercury Porosimeter, ARG-CHAR-DAM-16 Rev. 2, Date 5/25/05.

16. Data Acquisition Method, Preparation of Random Samples of Particles by Rotary Riffing, ARGCHAR-DAM-17 Rev. 1, Date 6/27/05.

17. Data Acquisition Method, Measurement of Pyrocarbon Anisotropy using the Two-Modulator Generalized Ellipsometry Microscope, ARG-CHAR-DAM-18 Rev. 0, Date 5/04/05.

18. Data Acquisition Method, Counting of Particles with Missing OPyC Layer by Visual Inspection, ARG-CHAR-DAM-19 Rev. 0, Date 4/15/05.

19. Data Acquisition Method, Counting of Particles with SiC Gold Defects by Visual Inspection, ARG-CHAR-DAM-20 Rev. 0, Date 4/15/05.

20. Data Acquisition Method, Measurement of Number of Particles with SiC Burn-Leach Defects, ARG-CHAR-DAM-21 Rev. 0, Date 4/21/05.

21. Data Acquisition Method, Estimation of Average Particle Weight, ARG-CHAR-DAM-22 Rev. 1, Date 6/14/05.

22. Standard Operating Procedure, Fluidized Bed Chemical Vapor Deposition System, AGR-COATSOP-01, Rev. 0, 05/25/05.

23. Standard Operating Procedure, Measurement of MTS Usage and Calculation of Vapor Flow, AGR-COAT-SOP-02, Rev. 0, 05/24/05.

24. Standard Operating Procedure, Tabling to Remove Highly Aspherical Particles, AGR-TABLESOP-01, Rev. 1, 9/08/05.

25. Standard Operating Procedure, Mass Flow Controller Calibration, AGR-MFCCALIBRATESOP-01, Rev. 0, 5/24/05.

26. Standard Operating Procedure, Size Classification of Particles, AGR-ROLLER-SOP-01, Rev. 0, 9/06/05. 